\section{Decrease in phagocytosis capacity of hemocyte during spawning in Mytilus edulis: a pilot study}

\author{
M. Fraser, ${ }^{1}$ P. Rault, ${ }^{2}$ \\ P-H. Roumier, ${ }^{3}$ M. Fortier, ${ }^{1}$ C. André, ${ }^{4}$ \\ P. Brousseau, ${ }^{1}$ F. Gagné, ${ }^{4}$ M. Fournier, ${ }^{1}$ \\ C. Surette, ${ }^{5}$ C. Vaillancourt ${ }^{1}$ \\ IINRS - Institut Armand-Frappier, \\ Université du Québec, Laval, QC, Canada; \\ ${ }^{2}$ Institut Universitaire Européen de la \\ Mer, Université de Bretagne Occidentale, \\ Plouzané, France; '3niversité Bordeaux I, \\ Talence, France; ${ }^{4}$ Environnement Canada, \\ Section de la recherche sur les écosys- \\ tèmes fluviaux, Montréal, QC, Canada; \\ 5Université de Moncton, Département de \\ chimie et de biochimie, Moncton, NB, \\ Canada
}

\section{Introduction}

During spawning in bivalves, important physiological systems are modulated. For example, an increase in serotonin (5-HT), a decrease of dopamine and an increase in the activity of cyclooxygenase (COX) are associated with spawning. ${ }^{1-5}$ In Elliptio complanata, females produce eggs containing egg-yolk proteins rich in vitellogenin (Vtg), and levels of these proteins decrease during the spawning period once eggs are released. ${ }^{6}$ In the Pacific oyster (Crassostrea gigas), it has also been shown that the organism reduces its metabolic activity after spawning due to a decrease in energy reserves. ${ }^{7,8}$ Moreover, a decrease in hematocyte phagocytosis, which plays a central role in bivalve defense, was observed during spawning in the mantle of Pacific oyster. ${ }^{\text {- }}$ ${ }^{10}$ A seasonal decrease, corresponding to the spawning period, of hemocyte phagocytosis was also featured in blue mussels (Mytilus edulis) from the Gulf of St. Lawrence. ${ }^{11,12}$ Despite this observation, it has not been clearly demonstrated that the decrease in phagocytosis in Mytilus edulis is due, among other things, to spawning. Thus the aim of this pilot study is to determine the effect of spawning on the immune response (phagocytosis) of Mytilus edulis.

\section{Materials and Methods}

\section{Animals}

Mytilus edulis were collected from the Baie de Plaisance located in the Illes de la Madeleine region $\left(47^{\circ} 29^{\prime} \mathrm{N}, 61^{\circ} 87^{\prime} \mathrm{W}\right)$. The specimens were placed in aerated tank filled with artificial sea water (Instant Ocean ${ }^{\circledR}$, Reef Crystal, Cincinnati, OH, USA) $\left(15^{\circ} \mathrm{C}\right.$, salinity $\left.31-1 \mathrm{psu}\right)$ and fed three times a week with phytoplankton (Phytoplex ${ }^{\circledR}$, Kent Marine, Franklin, WI, USA). Mussels were sacrificed one week before $(\mathrm{n}=12)$ and during $(\mathrm{n}=11)$ spawning period. The spawning period was determined by the release of gametes in the water.

\section{Gonads and hemolymph collection}

Before dissection, hemolymph was collected individually from the posterior adductor muscle using a $3 \mathrm{~mL}$ syringe and used immediately for phagocytosis and cell viability assays. For biomarkers measurement, mussels were kept in $20^{\circ} \mathrm{C}$. The mantles, containing gonads, were dissected on ice and homogenized with a Teflon pestle tissue grinder in a conservation buffer (Hepes-NaOH buffer (pH 7.4) containing 100 $\mathrm{mM} \mathrm{NaCl}, 0.1 \mathrm{mM}$ dithiothreitol and $1 \mu \mathrm{g} \mathrm{mL}-1$ aprotinin) as described in Gagné et al. ${ }^{13}$ The cytoplasmic fraction was obtained from a subsample of the homogenate as described in Gagné et al. ${ }^{6}$ Total proteins were determined using the Bradford method. ${ }^{14}$

\section{Gonads integrity}

Lipid peroxidation in mantle homogenates was determined using the thiobarbituric acid method which reacts with malonaldehyde following the oxidative breakdown of unsaturated phospholipids. ${ }^{15}$ Standards of tetramethoxypropane used for calibration and blanks were prepared in homogenization buffer. Fluorescence was measured at 540/35 excitation and $600 / 40 \mathrm{~nm}$ emission and results were expressed as thiobarbituric acid reactants/mg proteins.

\section{Spawning biomarker}

COX activity was measured as described by Gagné et al. ${ }^{6,13}$ using the oxidation of 2,7-dichlorofluorescin in the presence of arachidonate, previously described in Fijimoto et al. ${ }^{16,17}$ Briefly, S15 fraction were mixed with arachidonate, dichlorofluorescin and horseradish peroxidase in a Tris-HCL buffer ( $\mathrm{pH} \mathrm{8)}$ containing Tween 20. The appearance of fluorescein was measured every $2 \mathrm{~min}$ for $20 \mathrm{~min}$ at $485 \mathrm{~nm}$ (excitation) and $520 \mathrm{~nm}$ (emission) with a spectrofluorimeter (Spectra Max M5, Molecular devices). Results are expressed in relative fluorescence units/min/mg proteins. The levels of Vtg-like proteins were determined by the alkali-labile phosphate principle in acetone-fractionated proteins in the $\mathrm{S} 15$ fraction in order to determine if the mussels have spawned. ${ }^{18}$ Results are expressed in $\mu \mathrm{g}$ of phosphate/mg proteins.

\section{Cell viability and phagocytosis of hemocytes \\ The viability of hemocytes was evaluated by}

Correspondence: Michel Fournier and Cathy Vaillancourt, INRS - Institut Armand-Frappier, Université du Québec, Laval, QC, Canada.

E-mail: cathy.vaillancourt@iaf.inrs.ca;

michel.fournier@iaf.inrs.ca

Key words: phagocytosis, Mytilus edulis.

Conference presentation: part of this paper was presented at the ECOBIM meeting, 2013 May, Montréal, Quebec, Canada.

Contributions: Michel Fournier, CS, CV contributed equally.

This work is licensed under a Creative Commons Attribution NonCommercial 3.0 License (CC BYNC 3.0).

(C) Copyright M. Fraser et al., 2013

Licensee PAGEPress, Italy

Journal of Xenobiotics 2013; 3(s1):e12

doi:10.4081/xeno.2013.s1.e12

flow cytometry using the Guava PCA flow cytometer (Guava Technologies, Hayward, CA, USA) and the Viacount kit (Guava technologies) according to the supplier's instructions. Briefly, an aliquot of hemolymph was mixed with Viacount and 1000 events were recorded. Phagocytosis was assessed by determining by flow cytometry according to Brousseau et al..$^{19}$ Briefly, hemocytes were mixed with yellowgreen latex Fluoresbrite TM Carboxylate microspheres (Polysciences, Inc., Warrington, PA, USA), and incubated at $16^{\circ} \mathrm{C}$ in the dark. Additional beads were removed by centrifugation on a bovine serum albumin gradient. Acquisitions were performed using a FACSCalibur flow cytometer (Becton Dickinson, CA, USA) equipped with a $488 \mathrm{~nm}$ argon laser. For each sample, the fluorescence of 10,000 events was recorded in the region of interest.

\section{Statistical analysis}

Data are presented as mean standard error of the mean. The results were tested for normality by the Kolmogorov-Smirnov test. Significant differences were determined using Student's t-test. Variance homogeneity was verified by Levene's test. Pearson's correlations were performed between biomarkers and phagocytosis capacity. SPSS 20.0 was used for all statistical analyses (IBM corp, 2011).

\section{Results and Discussion}

Lipid peroxidation levels showed that gonad integrity was similar before and during spawning period ( $\mathrm{P}=0.825$, Figure $1 \mathrm{~A})$. For mussels 
still in the spawning period, no significant difference was observed in Vtg-like expression $(\mathrm{P}=0.471$, Figure 1B). This occurrence could be due to the proximity of the mussels living in the same aquarium. Eggs released from one mussel into the water could be recaptured by the same mussel or another. Moreover, mussels should have been sexed by histological analysis of gonads in order to distinguish the females in our Vtg expression results, as these proteins are generally found only in eggs. In bivalves, COX activity increases during spawning it was not statistically significant": $\left(\mathrm{P}=0.160\right.$; Figure 1C).$^{1-3}$ In this study, COX activity seemed to increase even though it was not statistically significant. It is possible that some mussels sacrificed in the spawning period were still not in spawning process. However, the negative correlation between COX activity and level of $\mathrm{Vtg}$ in the gonads $(\mathrm{r}=0.530$; $\mathrm{P}=0.009$; Table 1) gave a good indication that the mussels were, in fact, in spawning period. Moreover, phagocytosis activity in hemocytes was significantly and negatively correlated to COX activity in gonads $(\mathrm{r}=0.413 ; \mathrm{P}=0.05$; Table 1), which supports the hypothesis of the interaction of spawning on phagocytosis activity. Future experiments should include histological analysis of gonads during gametogenesis and the analysis of other spawning biomarkers, like serotonin and dopamine levels.

Hemocyte viability was not altered by the spawning period $(\mathrm{P}=0.111$; Figure 2). Nonspawning mussels showed a phagocytic capacity of $44 \%$ (Figure 2). Spawning induced a significant decrease of phagocytosis to reach $19 \%$ $(\mathrm{P}<0.009$; Figure 2$)$.

The decreased in immune response observed during spawning in Mytilus edulis in this study is consistent with the observation
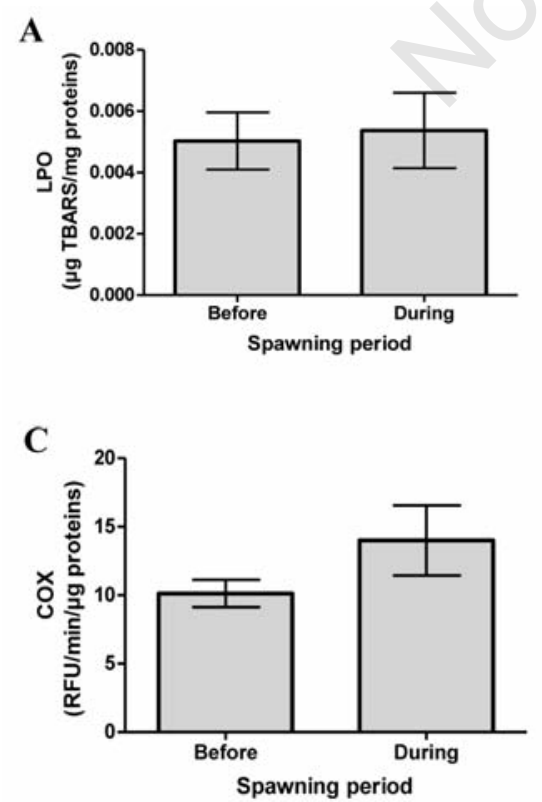

made by Cartier et al. ${ }^{12}$ They observed a decrease of phagocytosis in mussels from the Gulf of St. Lawrence corresponding to the spawning period. ${ }^{12}$ However, they were not able to make a direct link between those events. Nevertheless, a decrease in hematocyte phagocytosis was observed during spawning of Crassostrea gigas, ${ }^{7-10}$ which is consistent with this study. Li et al. show that energy reserves, based on glycogen and protein levels in the mantle of Pacific oysters, are also decreased during the spawning period. ${ }^{7}$ Thus, a trade-off of the energy to the spawning process could explain the effects on the immune response. This possibility should be tested for Mytilus edulis. Since the decrease of phagocytotic capacity occurs during spawning, it is also possible that the increased level of sex steroid hormones plays a suppressive role on the immune system, as was suggested by Cartier et al..$^{12,20}$ This phenomena was already demonstrated by Watanuki et al. in the head kidney of common carp. ${ }^{21}$ It would be interesting to monitor different hormones, like progesterone and estradiol, before, during and after spawning period of Mytilus edulis. Li et al. observed a recovery of phagocytotic capacity 8 days after the spawning in Pacific oysters. ${ }^{7}$ The same observation was made in Mytilus edulis after 7 days (data not shown). It would be useful to study extensively the impact of spawning on the immune system. During a period of reduced immune activity, it could be possible that mussels are more vulnerable to diseases. ${ }^{7-9,12}$

In conclusion, this preliminary study shows for the first time that spawning activity can be linked with a decreased in phagocytotic capacity in Mytilus edulis. A more complete study will be done based on the results presented here. It will be important to include histological analysis of the gonads in order to determine the gamatogenisis stage of each mussel. The impact of spawning should be considered in immunological studies in Mytilus edulis.

Table 1. Pearson's correlation between phagocytosis capacity of hemocytes and biomarkers (COX and Vtg) in Mytilus edulis.

\begin{tabular}{llccc} 
& & Phagocytosis & COX & Vtg \\
capacity & & & \\
\multirow{2}{*}{ Phagocytosis capacity } & r & 1 & $-0.413^{*}$ & -0.060 \\
& Sig. (2-tailed) & 1 & 0.050 & 0.787 \\
COX & r & $-0.413^{*}$ & 1 & $-0.530^{* *}$ \\
& Sig. (2-tailed) & 0.050 & 1 & 0.009 \\
\hline Vtg & r & -0.060 & $-0.530^{*}$ & 1 \\
& Sig. (2-tailed) & 787 & 0.009 & 1 \\
\hline
\end{tabular}

COX, cyclooxygenase; Vtg, vitellogenin. ${ }^{*} \mathrm{P}<0.05,{ }^{*} \mathrm{P}<0.01$

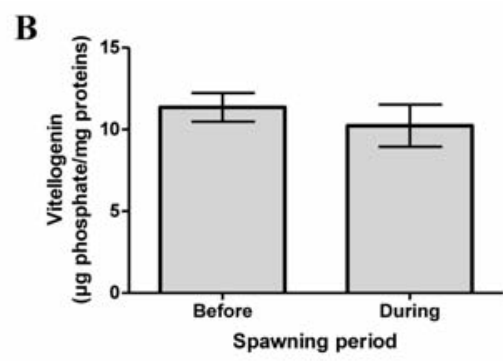

Figure 1. Analysis of (A) lipid peroxidation (LPO), (B) vitellogenin-like proteins and (C) in gonads of mussels before and during spawning period. No significant differences are observed. COX, cyclooxygenase.

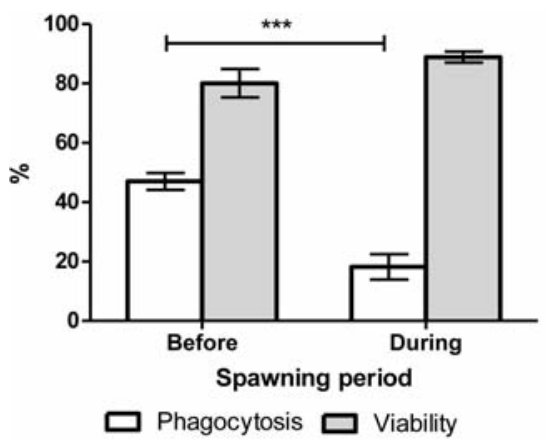

Figure 2. Phagocytic capacity and viability of hemocytes from Mytilus edulis before and during spawning period. ${ }^{* * *} \mathrm{P}<\mathbf{0 . 0 0 0 1}$. 


\section{References}

1. Morse DE, Duncan H, Hooker N, Morse A. Hydrogen peroxide induces spawning in mollusks, with activation of prostaglandin endoperoxide synthetase. Science 1977; 196:298-300.

2. Gagné F, Fournier M, Blaise C. Serotonergic effects of municipal effluents: Induced spawning activity in freshwater mussels. Fresenius Environ Bull 2004;13:1099-103.

3. Matsutani T, Nomura T. In vitro effects of serotonin and prostaglandins on release of eggs from the ovary of the scallop, Patinopecten yessoensis. General Comparat Endocrinol 1987;67:111-8.

4. Martínez G, Mettifogo L, Lenoir R, Olivares A. Prostaglandins and reproduction of the scallop Argopecten purpuratus: II. Relationship with gamete release. J Exp Zool 2000;287:86-91.

5. Fong PP, Noordhuis R, Ram JL. Dopamine reduces intensity of serotonin-induced spawning in the zebra mussel Dreissenapolymorpha (pallas). J Exp Zool 1993; 266:79-83.

6. Gagné F, André C, Cejka P, Hausler R, Fournier M. Evidence of neuroendocrine disruption in freshwater mussels exposed to municipal wastewaters. Sci Total Environ 2011;409:3711-8.

7. Li Y, Qin JG, Li X, Benkendorff K. Assessment of metabolic and immune changes in postspawning Pacific oyster Crassostrea gigas: identification of a critical period of vulnerability after spawning. Aquacult Res 2010;41:e155-65.

8. Li Y, Qin JG, Abbott CA, Li X, Benkendorff
K. Synergistic impacts of heat shock and spawning on the physiology and immune health of Crassostrea gigas: an explanation for summer mortality in Pacific oysters. Am J Physiol Regulat Integrat Comparat Physiol 2007;293:R2353-62.

9. Li Y, Qin JG, Li X, Benkendorff K. Spawning-dependent stress responses in pacific oysters Crassostrea gigas: a simulated bacterial challenge in oysters. Aquaculture 2009;293:164-71.

10. Rasmussen LPD, Hage E, Karlog 0. An electron microscope study of the circulating leucocytes of the marine mussel, Mytilus edulis. J Inverteb Pathol 1985;45: 158-67.

11. Lemaire N, Pellerin J, Fournier M, Girault L, Tamigneaux E, Cartier S, et al. Seasonal variations of physiological parameters in the blue mussel mytilus spp. from farm sites of eastern Quebec. Aquaculture 2006;261:729-51.

12. Cartier S, Pellerin J, Fournier M, Tamigneaux E, Girault L, Lemaire N. Use of an index based on the blue mussel (Mytilus edulis and Mytilus trossulus) digestive gland weight to assess the nutritional quality of mussel farm sites. Aquaculture 2004;241:633-54.

13. Gagne F, Bouchard B, André C, Farcy E, Fournier M. Evidence of feminization in wild Elliptio complanata mussels in the receiving waters downstream of a municipal effluent outfall. Comp Biochem Physiol C Toxicol Pharmacol 2011;153:99-106.

14. Bradford MM. Rapid and sensitive method for quantitation of microgram quantities of protein utilizing principle of protein-dye binding. Anal Biochem 1976;72:248-54.

15. Wills E. Evaluation of lipid peroxidation in lipids and biological membranes. In: Snell K, Mullok B, eds. Biochemical toxicology, a pratical approches. Oxford: IRL Press; 1987. pp 127-152.

16. Gagné F, Blaise C, Andre C, Gagnon C, Salazar M. Neuroendocrine disruption and health effects in Elliptio complanata mussels exposed to aeration lagoons for wastewater treatment. Chemosphere 2007; 68:731-43.

17. Fujimoto Y, Sakuma S, Inoue T, Uno E, Fujita T. The endocrine disruptor nonylphenol preferentially blocks cyclooxygenase-1. Life Sci 2002;70:2209-14.

18. Gagné F, André C, Bouchard B, Fournier M, Gagnon C. Neurotoxicological effects of aeration lagoon effluents for the treatment of domestic and hospital wastewaters on Elliptio complanata. In: Visser JE, ed. Ecotoxicology around the globe. New York, NY: Nova Science Publishers; 2010. pp 120.

19. Brousseau P, Payette Y, Tryphonas H, Blakley B, Boernaus H, Flipo D, et al. Manual of immunological methods. Boca Raton, FL: CRS Press; 1999.

20. Reis-Henriques MA, Le Guellec D, RemyMartin JP, Adessi GL. Studies of endogenous steroids from the marine mollusc Mytilus edulis L. By gas chromatography and mass spectrometry. Comp Biochem Physiol B Comp Biochem 1990;95:303-9.

21. Watanuki H, Yamaguchi T, Sakai M. Suppression in function of phagocytic cells in common carp Cyprinus carpio L. injected with estradiol, progesterone or 11ketotestosterone. Comp Biochem Physiol C Toxicol Pharmacol 2002;132:407-13. 